\title{
A Cross-Countries Research on the Duration of Export Trade Relationships in Manufacturing Industry
}

\author{
Hualin Pu, Ting Li \\ College of Economics, Jinan University, Guangzhou, China \\ Email: rita_liting@sina.com
}

How to cite this paper: $\mathrm{Pu}, \mathrm{H} . \mathrm{L}$. and $\mathrm{Li}, \mathrm{T}$. (2018) A Cross-Countries Research on the Duration of Export Trade Relationships in Manufacturing Industry. American Journal of Industrial and Business Management, 8, 850-866.

https://doi.org/10.4236/ajibm.2018.84059

Received: March 19, 2018

Accepted: April 21, 2018

Published: April 24, 2018

Copyright $\odot 2018$ by authors and Scientific Research Publishing Inc. This work is licensed under the Creative Commons Attribution International License (CC BY 4.0).

http://creativecommons.org/licenses/by/4.0/

(c) (i) Open Access

\begin{abstract}
China has accomplished itself as a great power in world manufacturing industry. However, China still has a long way to go compared with other advanced countries; and China does not have advantages in labor costs compared with some developing countries such as India and Vietnam. Therefore, the export trade of China, especially the export of manufacturing industry, is in face of an unprecedented crisis. And whether can we ensure the sustainability of export trade in manufacturing industry becomes particularly important. This paper, based on Survival Analysis, makes a study of the duration of export trade relationships of the top ten countries represented by China, America, and Germany in manufacturing sub-sectors from 1995 to 2015. We found that China can maintain a long time trade relationship in export trade of manufacturing. And we can know from the cross-countries comparison of median survival time and survival rate of manufacturing sub-sectors that China's export trade in manufacturing performs differently in different sub-sectors. And we should ensure the sustainability of export trade in manufacturing while simultaneously extend different treatment to different manufacturing sub-sectors.
\end{abstract}

\section{Keywords}

Export in Manufacturing Industry, Survival Analysis, Cross-Countries Comparison

\section{Introduction}

Since the policy of reform and opening up, China's manufacturing industry has scaled new highs and therefore acquired the status as the great power in manufacturing and the world's factory. According to the statistics, China has indeed 
become a major manufacturing country in the world. In 2010, according to the price and exchange rate of that year, China's manufacturing output accounted for $19.8 \%$ of the whole world, which ranked first surpassing America. In 2013, according to the constant price and exchange rate of 2005, the manufacturing output of China was 1.76 trillion dollars, which was slightly lower than America's 1.82 trillion dollars. China has more than 220 kinds of productions placed first all over the world among over 500 major industrial products [1]. In 2014, China became the largest country of automotive industry, producing about 24 million cars, which occupied $26 \%$ of the global market shares. And China is also the largest country in toy manufacturing, which accounts $70 \%$ of the global market shares. However, according to Deloitte's 2016 Global Manufacturing Competitiveness Index, a third of our country's export manufactured goods were low-skilled, low-tech, labor-intensive, and resource-intensive products. On one hand, compared with the advanced countries, China's manufacturing industry still has a long way to go. On the other hand, China's demographic dividend is now tailing off. Meanwhile, the developing countries represented by India and Vietnam have an edge over China in labor costs. From these two aspects, the export trade of China, especially the export of manufacturing industry, is facing an unprecedented crisis [2]. And whether can we ensure the sustainability of export trade in manufacturing industry becomes particularly important.

To study the sustainability of exports, we should define the concept of trade relationships and duration of trade relationships clearly first. Trade relationships are the status of involved enterprise or products from entering to quitting the market. The lasting time of the relation without interruption is defined as the duration of trade relationships, which was first proposed by Besedes and Prusa [3]. Ensuring the sustainability of export not only relies on build new trade relationships, but also on stabilizing the existing trade relationships. It will promote the sustainable development of exports if we conclude our country's advantages (that the duration of trade relationships is longer) compared with the advanced countries in manufacturing and formulate corresponding favorable policy.

The contribution of this paper is an innovation in research perspective. Based on the existing research, we subdivide the export trade relations of the manufacturing industry. As far as I know, nobody has studied in this perspective. The limitation of this paper is that we should study the factors affecting the export duration, and this research should be improved in the future.

The article is organized as follows: The first part is the introduction. In this part, we describe the background and significance of this paper. The second part is literature review. The third part is empirical analysis. The empirical results are composed of two parts: median survival times and survival rate. The last part is the conclusion and enlightenment of this paper.

\section{Literature Review}

As mentioned above, the earliest scholars on the duration of trade relationships 
are Besedes and Prusa [3] [4]. They firstly analyzed America's duration of import trade relationships based on Survival Analysis by using the 7-digit Tariff Schedule from 1972-1988 and HS10-digit product level data from 1989 to 2001 which was highly disaggregated. The results show that America's duration of trade relationships is remarkably short and have negative duration dependence, which means if a kind of products or an enterprise in a country could maintain import or export for years, the risk of failure would reduce. Therefore, it would tend to keep import or export for a long time in the future. Besides, they held the view that the differentiation of goods (such as homogeneous goods, reference priced products, and differentiated products) would influence the duration of trade relationships. After that, Nitsch [5] and Hess \& Person [6] both concluded the short duration of trade relationships through the study on the duration of trade relationships of Germany and the European Union respectively. Besede, T. and Juan B. [7] calculated Latin America's duration of exports and main driving factors of disparity between regions in the survival period. On the domestic front, Shao Jun [8] firstly analyzed the stability problem of China's exports from the perspective of duration, which used COMTRADE data HS1995-2007 and showed the duration of export trade relationships of China was short and decreased rapidly. Chen Yongbing et al. [9] calculated Chinese enterprise's exports duration and its determinant factors. And they did a further study from the two angles of agriculture products and enterprise heterogeneity [10] [11]. Lin Changqing [12] studied regularities of distribution and influencing factors of the trade duration of Chinese exports to America. Zhang Yabin et al. [2] made cross-countries comparison on the duration of export trade relationships in manufacturing. Chen Xiaohua and Shen Chengyan [13] firstly connected duration of exports with the quality of products, and drew a conclusion that the export of China is "Low-end Locked" and "Inertia of quality innovation".

Throughout the above researches, the duration of trade relationships has been studied from the perspective of import and export, large-scale agriculture, large-scale manufacture, and cross-countries comparison respectively. But there are few literatures to analyze the manufacturing sub-sectors as the main target, and there are few literatures to make cross-countries comparison between China and other manufacturing powers from the perspective of manufacturing sub-sectors. Therefore, this paper takes products in manufacturing sub-sectors for research objects and makes a comparative study of the Top 10 countries in 2016 Global Manufacturing Competitiveness Index which was issued by Deloitte and the US Council on Competitiveness. This will help the manufacturing industry in China, which is regarded as the great power in manufacturing, have a better understanding and fixed position of maintaining the export sustainability, and its importance is self-evident.

\section{Modelling Duration}

\subsection{Duration Models}

Survival analysis is a branch of statistics for measuring the time to a certain 
event, which is widely used in medicine, sociology, biology, and insurance studies. Survival time is to measure the time that one event occurs, such as death, relapses, the development of a given disease, parole, or divorce. These "time" is effected by random variations, which can form a distribution like any random variations. The distribution of survival times is usually described by the following three functions: 1) the survivorship function; 2) the probability density function; 3 ) the hazard function. The basic questions in survival analysis are to estimate one or more functions from the above three and infer the overall survival mode. In this paper, the duration of trade relationships is a kind of survival time's statement in trade studies.

Besedeš and Prusa [3] is the earliest ones who creatively used survival function and hazard rate to describe the distributive characteristics of America's duration of import trade relationships. This paper will build the export survival function and hazard function to estimate distributive characteristics of duration of trade relationships on China and other nine countries in manufacturing industry. Let $T$ be a survival time of a certain trade relationship. We assume $T$ is a discrete random variable taking on values $t_{i}, i=1,2,3, \cdots, n$, then the survival function about survival time $T$ is expressed by $S_{i}(t)$, which is defined as the probability that this trade relationship is longer that $t$.

$$
S_{i}(t)=\operatorname{Pr}\left(T_{i}>t\right)
$$

When $T=0, S(t)=1$; When $T \rightarrow \infty, S(t)=0$. That's to say, at the beginning of trade, the probability of exports is 1 ; and if time is approaching infinity, the probability of exports is 0 .

The hazard function $h(t)$ is

$$
h_{i}(t)=\operatorname{Pr}\left(t-1<T_{i} \leq t \mid T_{i}>t-1\right)=\frac{P\left(t-1<T_{i} \leq t\right)}{P\left(T_{i}>t-1\right)}
$$

The relationship between survival function and hazard function is

$$
S_{i}(t)=\prod_{t_{i}<t}[1-h(t)]
$$

Due to the unknown of the distribution characteristics of trade relationships, Kaplan and Meier put forward product-limit (PL) method to do non-parametric estimation to survival function, the estimate is as follows:

$$
\widehat{S(t)}=\prod_{t_{(i)}<t} \frac{n_{i}-d_{i}}{n_{i}}
$$

Hereinto, $n_{i}$ denote the number of subjects at risk of failing at $d_{i}$. And denote the rank-ordered survival times as $t_{(1)} \leq t_{(2)} \leq \cdots \leq t_{(i)} \leq \cdots \leq t_{(i)}, \quad d_{i}$ denote the number of observed failures.

The hazard function is estimated by taking the ratio of subjects who fail to the number of subjects at risk in a given period $i$,

$$
\widehat{h(t)}=\frac{d_{i}}{n_{i}}
$$




\subsection{Data and Data Processing}

This paper defines the duration of trade relationships as the length of time an enterprise or products export or import to a country (without interruption). From the annual data of the trade relationships, we can conclude the duration of trade of that kind of products, which is the length of time product $\mathrm{p}$ entering to country $j$ until quitting the market (without interruption). We refer to an event as a "failure" if a country ceases to export a product.

When applying the survival analysis to estimate the duration, we should pay attention to two data characteristics: 1) Multiple Spells, which means during the observation period, a country will service the market, exit, then re-enter the market, and then almost always exit again. Besedeš and Prusa (2006b)'s research shows that multiple spells are interdependent with each other, which means that the multiple spells do not influence the distribution of the duration's length substantially. Therefore, this paper follows this conclusion, and regards the first spell as the only spell. 2) Censoring. We used the data from 1995 to 2015 to study the duration of trade relationships, so we cannot foresee the export situations after 2015. Therefore, the right censoring exists. Survival analysis can deal with this problem properly. Similarly, we cannot get the export condition before 1995. If the product has exports before 1995, we cannot get the duration that it had already exported. Therefore, the left censoring appears. Referring to Chen Yongbing's method [9], this paper will get rid of left censoring data, which means keep the data that export between 1996 and 2015 but did not export before 1995. Consequently, the longest length of the duration is 20 years.

The data of this paper is from the BACI data base provided by CEPII in terms of HS6-digit product level data from 1995 to 2015, which is adjusted on the base of the initial data of United Nations Statistical Division (COMTRADE database). The latest data that we can obtain from COMTRADE database is up to 2015, so we use the period 1995 to 2015 as the sample. The advantage of CEPII BACI data base lies on the data is processed, which prevents from the problem that the data of the product cannot matche due to the change of coding. Our research object is manufacturing sub-sectors, but the CEPII BACI data base does not have the classification of manufacturing sub-sectors. Since now we do not have a direct way to distinguish it, this paper refers to Bin sheng's method. Through the contrast list of HS 1992 and SITC Rev.3, we can get the HS1992 code and the corresponding situations in manufacturing sub-sectors.

We choose the Top 10 countries in 2016 Global Manufacturing Competitiveness Index (GMCI) which was issued by Deloitte and the US Council on Competitiveness. And we estimate the overall distribution of export duration in manufacturing sub-sectors of these countries. After the exclusion of the Taiwan, the selected countries are China, America, Germany, Japan, Korea, the UK, Mexico, Canada, Singapore and India.

As illustrated in Table 1, this paper gives the descriptive statistics of the export duration of the top 10 countries in HS 1992 6-digit of manufacturing 
Table 1. Descriptive statistics of the export duration of top 10 countries in manufacturing industry.

\begin{tabular}{ccc}
\hline Country & Total Observation Sample & Trade Relationships Sample \\
\hline China & $6,044,148$ & 5526 \\
America & $6,261,393$ & 5786 \\
Germany & $6,414,253$ & 5875 \\
Japan & $3,346,539$ & 5350 \\
Korea & $2,625,629$ & 5340 \\
The UK & $5,233,296$ & 5850 \\
Mexico & $1,330,380$ & 4578 \\
Canada & $1,991,215$ & 5333 \\
Singapore & $1,900,819$ & 5132 \\
India & $3,212,655$ & 5549 \\
\hline
\end{tabular}

Source: Authors calculation results.

products. The total observation sample is the record of export of each country before censoring. This index shows the manufacturing industry's export performance of each country from 1995 to 2015. According to Table 1, all the ten countries have more than a million record in manufacturing exports, among which China, America and Germany are the most in observation samples. In the past 21 years, these three countries have had more than 6 million export records in manufacturing industry, which shows that the export of manufacturing products in the three countries is very active. And the sample of trade relationship is the sum of each country's trade relationships in manufacturing sub-sectors from 1995 to 2015. Except for Mexico, there are more than 5000 trade relations in the rest of the nine countries, and the quantity is roughly similar.

\section{Empirical Results}

\subsection{The Cross-Countries Comparison of the Median Survival Time}

The most frequently used summary statistics in survival analysis is the median survival time, which is the $50 \%$ quantile (median) of the survival time. The mean value is usually used to describe the central trend of a distribution. But as for survival distribution, the median is more appropriate than the mean value because a very long or particularly short duration of export trade will have a significant impact on the mean value (average survival time). The estimated value of the median survival time is the quantile of $(S(t))=50 \%$, which is the time $\mathrm{t}$ that can satisfy $(S(t))=0.5$. It must be noted that, we cannot estimate the median survival time if the number of failure events is less than half and the largest data is right censored.

According to the estimation of median survival time, we conclude the ten countries' median survival time in manufacturing sub-sectors. The result is shown as shown in Table 2. 
Table 2. Cross-countries comparison of median survival time.

\begin{tabular}{|c|c|c|c|c|c|c|c|c|c|c|c|c|c|}
\hline $\begin{array}{l}\text { Manufacturing } \\
\text { Sub-sectors }\end{array}$ & China & America & Germany & Japan & Korea & a The UK & Mexico & Canada & a Singapore & India & $\begin{array}{l}\text { The } \\
\text { Mean } \\
\text { Value }\end{array}$ & $\begin{array}{l}\text { If China is } \\
\text { less than the } \\
\text { average } \\
(\text { Yes }=1 \\
\text { No }=0)\end{array}$ & $\begin{array}{l}\text { China's ranking } \\
\text { (from high to } \\
\text { low) }\end{array}$ \\
\hline $\begin{array}{l}\text { Manufacturing } \\
\text { industry }\end{array}$ & 2 & 2 & 2 & 1 & 2 & 2 & 1 & 2 & 2 & 2 & 1.8 & 0 & - \\
\hline $\begin{array}{l}\text { Food processing and } \\
\text { manufacturing }\end{array}$ & 5 & 4 & 3 & 2 & 1 & 3 & 2 & 2 & 3 & 3 & 2.8 & 0 & 1 \\
\hline Beverage industry & 2 & 2 & 2 & 1 & 2 & 2 & 2 & 1 & 1 & 2 & 1.7 & 0 & 1 \\
\hline $\begin{array}{c}\text { Tobacco processing } \\
\text { industry }\end{array}$ & 1 & 2 & 2 & 1 & 3 & 2 & 1 & 1 & 1 & 1 & 1.5 & 1 & 5 \\
\hline Textile industry & 4 & 4 & 6 & 2 & 2 & 4 & 2 & 2 & 2 & 13 & 4.1 & 1 & 3 \\
\hline $\begin{array}{l}\text { Manufacture of } \\
\text { clothing and other } \\
\text { fiber products }\end{array}$ & 3 & 2 & 3 & 1 & 2 & 3 & 2 & 1 & 2 & 4 & 2.3 & 0 & 2 \\
\hline $\begin{array}{l}\text { Leather feathers and } \\
\text { feathers and their } \\
\text { products industry }\end{array}$ & 4 & 2 & 1 & 1 & 1 & 2 & 1 & 2 & 2 & 2 & 1.8 & 0 & 1 \\
\hline $\begin{array}{l}\text { Wood processing } \\
\text { and grass and } \\
\text { bamboo products } \\
\text { industry }\end{array}$ & 3 & 1 & 1 & 1 & 1 & 1 & 1 & 1 & 1 & 1 & 1.2 & 0 & 1 \\
\hline Furniture industry & 5 & 2 & 3 & 1 & 1 & 1 & 1 & 3 & 2 & 1 & 2 & 0 & 1 \\
\hline $\begin{array}{l}\text { Paper making and } \\
\text { paper industry }\end{array}$ & 3 & 2 & 2 & 1 & 1 & 2 & 1 & 1 & 2 & 1 & 1.6 & 0 & 1 \\
\hline $\begin{array}{l}\text { Copy of printing } \\
\text { media }\end{array}$ & 2 & 2 & 3 & 1 & 1 & 3 & 1 & 4 & 1 & 1 & 1.9 & 0 & 4 \\
\hline $\begin{array}{c}\text { Cultural and } \\
\text { educational sports } \\
\text { goods manufacturing } \\
\text { industry }\end{array}$ & 4 & 5 & 3 & 1 & 2 & 3 & 2 & 3 & 2 & 2 & 2.7 & 0 & 2 \\
\hline $\begin{array}{l}\text { Petroleum } \\
\text { processing and } \\
\text { coking industry }\end{array}$ & 3 & 1 & 1 & 2 & 2 & 2 & 1 & 1 & 2 & 1 & 1.6 & 0 & 1 \\
\hline $\begin{array}{l}\text { Chemical raw } \\
\text { materials and } \\
\text { chemical products } \\
\text { manufacturing } \\
\text { industry }\end{array}$ & 4 & 4 & 4 & 1 & 2 & 3 & 1 & 1 & 3 & 4 & 2.7 & 0 & 1 \\
\hline $\begin{array}{l}\text { Pharmaceutical } \\
\text { manufacturing } \\
\text { industry }\end{array}$ & 2 & 1 & 1 & 1 & 1 & 1 & 1 & 1 & 1 & 1 & 1.1 & 0 & 1 \\
\hline $\begin{array}{l}\text { Chemical fiber } \\
\text { manufacturing } \\
\text { industry }\end{array}$ & 1 & 1 & 2 & 1 & 2 & 1 & 1 & 1 & 1 & 1 & 1.2 & 1 & 3 \\
\hline $\begin{array}{l}\text { Rubber products } \\
\text { industry }\end{array}$ & 4 & 1 & 3 & 4 & 3 & 2 & 1 & 2 & 1 & 2 & 2.3 & 0 & 1 \\
\hline
\end{tabular}




\section{Continued}

\begin{tabular}{|c|c|c|c|c|c|c|c|c|c|c|c|c|c|}
\hline Plastics industry & 5 & 2 & 2 & 2 & 2 & 2 & 1 & 2 & 2 & 2 & 2.2 & 0 & 1 \\
\hline $\begin{array}{l}\text { Nonmetallic mineral } \\
\text { products industry }\end{array}$ & 3 & 2 & 3 & 2 & 2 & 2 & 1 & 1 & 1 & 1 & 1.8 & 0 & 1 \\
\hline $\begin{array}{l}\text { Ferrous metal } \\
\text { smelting and } \\
\text { calendaring industry }\end{array}$ & 3 & 2 & 2 & 1 & 2 & 2 & 1 & 1 & 1 & 3 & 1.8 & 0 & 1 \\
\hline $\begin{array}{l}\text { Nonferrous metal } \\
\text { smelting and } \\
\text { calendaring } \\
\text { processing industry }\end{array}$ & 3 & 2 & 2 & 1 & 1 & 2 & 1 & 2 & 1 & 2 & 1.7 & 0 & 1 \\
\hline $\begin{array}{c}\text { Metal } \\
\text { products industry }\end{array}$ & 2 & 4 & 3 & 2 & 1 & 3 & 1 & 3 & 1 & 2 & 2.2 & 1 & 5 \\
\hline $\begin{array}{c}\text { General machinery } \\
\text { manufacturing } \\
\text { industry }\end{array}$ & 4 & 6 & 9 & 1 & 3 & 3 & 1 & 2 & 3 & 2 & 3.4 & 0 & 3 \\
\hline $\begin{array}{l}\text { Special equipment } \\
\text { manufacturing } \\
\text { industry }\end{array}$ & 2 & 5 & 4 & 2 & 2 & 3 & 1 & 2 & 2 & 2 & 2.5 & 1 & 4 \\
\hline $\begin{array}{l}\text { Transportation } \\
\text { equipment } \\
\text { manufacturing } \\
\text { industry }\end{array}$ & 5 & 4 & 3 & 2 & 7 & 3 & 1 & 2 & 2 & 2 & 3.1 & 0 & 2 \\
\hline $\begin{array}{l}\text { Electrical machinery } \\
\text { and equipment } \\
\text { manufacturing }\end{array}$ & 3 & 3 & 5 & 4 & 2 & 3 & 2 & 2 & 3 & 2 & 2.9 & 0 & 3 \\
\hline $\begin{array}{l}\text { Electronic and } \\
\text { communication } \\
\text { equipment } \\
\text { manufacturing } \\
\text { industry }\end{array}$ & 2 & 2 & 3 & 2 & 2 & 3 & 1 & 2 & 2 & 1 & 2 & 0 & 3 \\
\hline $\begin{array}{l}\text { Instrument and } \\
\text { cultural office } \\
\text { machinery }\end{array}$ & 2 & 2 & 3 & 2 & 1 & 3 & 1 & 3 & 1 & 2 & 2 & 0 & 4 \\
\hline
\end{tabular}

Source: Authors calculation results.

Data in the first line of Table 2 is the median of the duration of the export of manufacturing industry in each country. Except for the data in the first line, the rest is the median survival time in manufacturing sub-sectors of each country. From the perspective of the whole manufacturing industry, except for the median of India and Mexico which is 1 year, the median of other countries is 2 years. The median difference is slight, which seems that China has been in the same echelon with manufacturing great powers. But from the subdivision of the manufacturing sub-sectors, the median of China's export trade relations has different performance in different industries.

From the overall results, the median survival time of all the ten countries in manufacturing sub-sectors is relatively short, which is generally between $1-4$ 
years. From the manufacturing sub-sectors, the median survival time of China is generally longer than other countries. Except for the tobacco processing industry, textile industry, chemical fiber manufacturing industry, metal products industry and special equipment manufacturing industry, the median survival time of China is longer than the average survival time of the other ten countries, which indicates that most manufacturing industry sub-sectors in China can maintain long trade relationships in export trade. As for the reason why the textile industry, which is regarded as the China's traditional ascendant export industry, has the mean value which is lower than the average of the ten countries, it mainly lies in two aspects: one is due to the influence of left censoring, which deleted a large number of long-term export trade relations before 1995, resulting that the median survival time of Chinese textile industry is relatively short; On the other hand, the survival time of India raised the mean value. Without considering the time in India, the mean value of median survival time of the remaining nine is 3.1, and China exceeds this average value. In China's manufacturing industry, the longest median survival time is 5 years and the sectors are food processing and manufacturing, furniture products, plastic products and transportation equipment manufacturing. And China has 15 sub-sectors' survival time ranks first by long to short, which are food processing and manufacturing, beverage manufacturing, leather fur and feather products industry, wood processing and grass and bamboo products industry, furniture industry, paper and paper products industry, petroleum processing and coking industry, chemical materials and chemical products manufacturing, pharmaceutical manufacturing, rubber products industry, non-metallic mineral products industry, ferrous metal smelting and rolling processing industry, non-ferrous metal smelting and rolling processing industry, etc. Overall, the result of median survival time shows that most sub-sectors of China's manufacturing have been in the world's leading position while maintaining export trade relationships.

According to the median survival time of the manufacturing sub-sectors, China's export trade has different performances in different sub-sectors. However, the previous study only focused on the whole manufacturing trade duration, which cannot find which sub-sector has more export advantages. Therefore, the above analysis confirms the importance of the research on the duration of the products in the manufacturing sub-sectors from the specific data.

\subsection{The Cross-Countries Comparison of the Survival Rate on Export Trade}

To depict more details of the duration of export trade relationships, besides the median survival time, we use PL method to further estimate the survival rate of export trade relationships of the manufacturing sub-sectors. The length of all trade relationships varies from 1 to 20 years. In order to display the empirical results more efficiently, we selected 1, 2, 3, 4, 10 and 20 years as observation nodes, and the results are shown in Table 3. 
Table 3. Comparison of survival rate of products in manufacturing sub-sectors.

\begin{tabular}{|c|c|c|c|c|c|c|c|c|c|c|}
\hline $\begin{array}{l}\text { The length of } \\
\text { duration }\end{array}$ & China & American & Germany & Japan & Korea & The UK & Mexico & Canada & Singapore & India \\
\hline \multicolumn{11}{|c|}{ Food processing and manufacturing } \\
\hline 1 & $68.42 \%$ & $75.00 \%$ & $70.97 \%$ & $53.45 \%$ & $47.83 \%$ & $72.00 \%$ & $54.95 \%$ & $69.23 \%$ & $62.90 \%$ & $59.09 \%$ \\
\hline 2 & $60.53 \%$ & $67.86 \%$ & $51.61 \%$ & $31.03 \%$ & $40.58 \%$ & $56.00 \%$ & $40.66 \%$ & $46.15 \%$ & $53.23 \%$ & $50.00 \%$ \\
\hline 3 & $57.89 \%$ & - & $38.71 \%$ & $25.86 \%$ & $33.33 \%$ & $44.00 \%$ & $34.07 \%$ & $38.46 \%$ & $46.77 \%$ & $42.42 \%$ \\
\hline 5 & $50.00 \%$ & $32.14 \%$ & $25.81 \%$ & $18.97 \%$ & - & $32.00 \%$ & $25.27 \%$ & $30.77 \%$ & $20.97 \%$ & $31.82 \%$ \\
\hline 10 & $42.11 \%$ & $21.43 \%$ & $9.68 \%$ & - & $21.74 \%$ & $20.00 \%$ & - & $23.08 \%$ & $11.29 \%$ & $25.76 \%$ \\
\hline 20 & $18.42 \%$ & $0.00 \%$ & $3.23 \%$ & $5.17 \%$ & $7.25 \%$ & $8.00 \%$ & $7.69 \%$ & $5.77 \%$ & $1.61 \%$ & $9.09 \%$ \\
\hline decline & $73.08 \%$ & I & $95.45 \%$ & $90.33 \%$ & $84.84 \%$ & $88.89 \%$ & $86.01 \%$ & $91.67 \%$ & $97.44 \%$ & $84.62 \%$ \\
\hline \multicolumn{11}{|c|}{ Beverage industry } \\
\hline 1 & $60.26 \%$ & $52.17 \%$ & $58.00 \%$ & $46.79 \%$ & $56.56 \%$ & $56.00 \%$ & $56.96 \%$ & $50.00 \%$ & $44.86 \%$ & $55.81 \%$ \\
\hline 2 & $46.15 \%$ & $28.26 \%$ & $38.00 \%$ & $29.36 \%$ & $37.70 \%$ & $48.00 \%$ & $43.04 \%$ & $32.50 \%$ & $28.04 \%$ & $32.56 \%$ \\
\hline 3 & $34.62 \%$ & - & $32.00 \%$ & $21.10 \%$ & $27.05 \%$ & $40.00 \%$ & $36.71 \%$ & $27.50 \%$ & $18.69 \%$ & $25.58 \%$ \\
\hline 5 & $25.64 \%$ & $23.91 \%$ & $24.00 \%$ & $16.51 \%$ & - & $28.00 \%$ & $31.65 \%$ & $20.00 \%$ & $10.28 \%$ & $16.28 \%$ \\
\hline 10 & $23.08 \%$ & $8.70 \%$ & $16.00 \%$ & $10.09 \%$ & $15.57 \%$ & $12.00 \%$ & $20.25 \%$ & $13.75 \%$ & $5.61 \%$ & $12.79 \%$ \\
\hline 20 & $5.13 \%$ & $2.17 \%$ & $4.00 \%$ & $2.75 \%$ & $3.28 \%$ & $4.00 \%$ & $8.86 \%$ & $5.00 \%$ & $0.00 \%$ & $4.65 \%$ \\
\hline decline & $91.49 \%$ & $95.84 \%$ & $93.10 \%$ & $94.12 \%$ & $94.20 \%$ & $92.86 \%$ & $84.45 \%$ & $90.00 \%$ & I & $91.67 \%$ \\
\hline \multicolumn{11}{|c|}{ Tobacco processing industry } \\
\hline 1 & $44.20 \%$ & $55.17 \%$ & $51.81 \%$ & $22.45 \%$ & $73.88 \%$ & $59.26 \%$ & $46.84 \%$ & $29.85 \%$ & $35.71 \%$ & $45.30 \%$ \\
\hline 2 & $21.74 \%$ & $37.93 \%$ & $34.94 \%$ & $2.04 \%$ & $58.21 \%$ & $38.89 \%$ & $25.32 \%$ & $13.43 \%$ & $21.43 \%$ & $24.79 \%$ \\
\hline 3 & $15.22 \%$ & $27.59 \%$ & $26.51 \%$ & $0.00 \%$ & $22.39 \%$ & $24.07 \%$ & $16.46 \%$ & $5.97 \%$ & $16.67 \%$ & $17.09 \%$ \\
\hline 5 & $8.70 \%$ & $13.79 \%$ & - & $0.00 \%$ & $9.70 \%$ & $22.22 \%$ & $11.39 \%$ & $1.49 \%$ & $3.57 \%$ & $8.55 \%$ \\
\hline 10 & - & $6.90 \%$ & $10.84 \%$ & $0.00 \%$ & - & $11.11 \%$ & - & $0.00 \%$ & - & - \\
\hline 20 & $0.00 \%$ & $1.72 \%$ & $4.82 \%$ & $0.00 \%$ & $1.49 \%$ & $1.85 \%$ & $0.00 \%$ & $0.00 \%$ & $0.00 \%$ & $0.85 \%$ \\
\hline decline & 1 & $96.88 \%$ & $90.70 \%$ & 1 & $97.98 \%$ & $96.88 \%$ & 1 & 1 & 1 & $98.12 \%$ \\
\hline \multicolumn{11}{|c|}{ Textile industry } \\
\hline 1 & $72.73 \%$ & $82.76 \%$ & - & $53.13 \%$ & $55.32 \%$ & $69.57 \%$ & $54.55 \%$ & $61.19 \%$ & $54.67 \%$ & $75.61 \%$ \\
\hline 2 & $63.64 \%$ & $55.17 \%$ & $88.00 \%$ & $40.63 \%$ & $40.43 \%$ & $65.22 \%$ & $32.47 \%$ & $46.27 \%$ & $38.67 \%$ & $70.73 \%$ \\
\hline 3 & $54.55 \%$ & - & $72.00 \%$ & $31.25 \%$ & $36.17 \%$ & $52.17 \%$ & $23.38 \%$ & $41.79 \%$ & $29.33 \%$ & - \\
\hline 5 & $45.45 \%$ & $37.93 \%$ & $52.00 \%$ & $15.63 \%$ & $27.66 \%$ & $39.13 \%$ & $12.99 \%$ & $32.84 \%$ & - & $65.85 \%$ \\
\hline 10 & $31.82 \%$ & $20.69 \%$ & $28.00 \%$ & $3.13 \%$ & $19.15 \%$ & $8.70 \%$ & - & $26.87 \%$ & $13.33 \%$ & $58.54 \%$ \\
\hline 20 & $9.09 \%$ & $10.34 \%$ & $0.00 \%$ & $0.00 \%$ & $6.38 \%$ & $0.00 \%$ & $1.30 \%$ & $8.96 \%$ & $2.67 \%$ & $39.02 \%$ \\
\hline decline & $87.50 \%$ & $87.51 \%$ & I & 1 & $88.47 \%$ & I & $97.62 \%$ & $85.36 \%$ & $95.12 \%$ & $48.39 \%$ \\
\hline \multicolumn{11}{|c|}{ Manufacture of clothing and other fiber products } \\
\hline 1 & $62.96 \%$ & $53.66 \%$ & $75.68 \%$ & $40.74 \%$ & $53.85 \%$ & $64.86 \%$ & $51.09 \%$ & $45.83 \%$ & $53.16 \%$ & $60.78 \%$ \\
\hline 2 & $55.56 \%$ & $36.59 \%$ & $54.05 \%$ & $25.93 \%$ & $38.46 \%$ & $56.76 \%$ & $34.78 \%$ & $33.33 \%$ & $36.71 \%$ & $54.90 \%$ \\
\hline 3 & $48.15 \%$ & $29.27 \%$ & $40.54 \%$ & $18.52 \%$ & $30.77 \%$ & $40.54 \%$ & $30.43 \%$ & $20.83 \%$ & $25.32 \%$ & $52.94 \%$ \\
\hline 5 & $37.04 \%$ & $19.51 \%$ & $29.73 \%$ & $14.81 \%$ & $17.31 \%$ & $32.43 \%$ & $19.57 \%$ & $15.28 \%$ & $15.19 \%$ & $41.18 \%$ \\
\hline 10 & $25.93 \%$ & $14.63 \%$ & $8.11 \%$ & $7.41 \%$ & $11.54 \%$ & $16.22 \%$ & $11.96 \%$ & $11.11 \%$ & $7.59 \%$ & $33.33 \%$ \\
\hline 20 & $3.70 \%$ & $2.44 \%$ & $2.70 \%$ & $1.85 \%$ & $1.92 \%$ & $8.11 \%$ & $7.61 \%$ & $1.39 \%$ & $1.27 \%$ & $15.69 \%$ \\
\hline decline & $94.12 \%$ & $95.45 \%$ & $96.43 \%$ & $95.46 \%$ & $96.43 \%$ & $87.50 \%$ & $85.10 \%$ & $96.97 \%$ & $97.61 \%$ & $74.19 \%$ \\
\hline
\end{tabular}




\section{Continued}

\begin{tabular}{|c|c|c|c|c|c|c|c|c|c|c|}
\hline \multicolumn{11}{|c|}{ Leather feathers and feathers and their products industry } \\
\hline 1 & $74.07 \%$ & $57.14 \%$ & $47.06 \%$ & $48.33 \%$ & $50.00 \%$ & $60.00 \%$ & $35.80 \%$ & $50.54 \%$ & $50.75 \%$ & $58.11 \%$ \\
\hline 2 & $62.96 \%$ & $38.78 \%$ & $38.24 \%$ & $28.33 \%$ & $38.33 \%$ & $45.00 \%$ & $20.99 \%$ & $40.86 \%$ & $34.33 \%$ & $47.30 \%$ \\
\hline 3 & $51.85 \%$ & $36.73 \%$ & $29.41 \%$ & $16.67 \%$ & $33.33 \%$ & $35.00 \%$ & $13.58 \%$ & $35.48 \%$ & $23.88 \%$ & $41.89 \%$ \\
\hline 5 & $40.74 \%$ & $28.57 \%$ & $17.65 \%$ & $10.00 \%$ & $20.00 \%$ & $25.00 \%$ & $6.17 \%$ & $25.81 \%$ & $11.94 \%$ & $35.14 \%$ \\
\hline 10 & $29.63 \%$ & $18.37 \%$ & $11.76 \%$ & $6.67 \%$ & - & $10.00 \%$ & - & $16.13 \%$ & - & $25.68 \%$ \\
\hline 20 & $11.11 \%$ & $12.24 \%$ & $0.00 \%$ & $1.67 \%$ & $3.33 \%$ & $2.50 \%$ & $2.47 \%$ & $4.30 \%$ & $0.00 \%$ & $9.46 \%$ \\
\hline decline & $85.00 \%$ & $78.58 \%$ & I & $96.54 \%$ & $93.34 \%$ & $95.83 \%$ & $93.10 \%$ & $91.49 \%$ & I & $83.72 \%$ \\
\hline \multicolumn{11}{|c|}{ Wood processing and grass and bamboo products industry } \\
\hline 1 & $67.74 \%$ & $45.21 \%$ & $47.37 \%$ & $40.24 \%$ & $35.48 \%$ & $35.09 \%$ & $37.50 \%$ & $47.52 \%$ & $37.21 \%$ & $45.92 \%$ \\
\hline 2 & $51.61 \%$ & $34.25 \%$ & $31.58 \%$ & $20.73 \%$ & $24.73 \%$ & $26.32 \%$ & $19.44 \%$ & $32.67 \%$ & $23.26 \%$ & $35.71 \%$ \\
\hline 3 & $45.16 \%$ & $26.03 \%$ & $28.07 \%$ & $13.41 \%$ & $18.28 \%$ & $21.05 \%$ & $15.28 \%$ & $27.72 \%$ & $17.44 \%$ & $24.49 \%$ \\
\hline 5 & $38.71 \%$ & $17.81 \%$ & $19.30 \%$ & $4.88 \%$ & $8.60 \%$ & $14.04 \%$ & $9.72 \%$ & $17.82 \%$ & $11.63 \%$ & $22.45 \%$ \\
\hline 10 & $29.03 \%$ & $9.59 \%$ & $10.53 \%$ & - & - & $7.02 \%$ & - & - & $3.49 \%$ & $14.29 \%$ \\
\hline 20 & $4.84 \%$ & $0.00 \%$ & $5.26 \%$ & $0.00 \%$ & $0.00 \%$ & $5.26 \%$ & $2.78 \%$ & $2.97 \%$ & $1.16 \%$ & $2.04 \%$ \\
\hline decline & $92.86 \%$ & 1 & $88.90 \%$ & I & 1 & $85.01 \%$ & $92.59 \%$ & $93.75 \%$ & $96.88 \%$ & $95.56 \%$ \\
\hline \multicolumn{11}{|c|}{ Furniture industry } \\
\hline 1 & $76.92 \%$ & $60.26 \%$ & $76.60 \%$ & $43.55 \%$ & $44.32 \%$ & $46.67 \%$ & $36.63 \%$ & $65.12 \%$ & $59.70 \%$ & $48.33 \%$ \\
\hline 2 & $65.38 \%$ & $47.44 \%$ & $57.45 \%$ & $27.42 \%$ & $32.95 \%$ & $40.00 \%$ & $22.77 \%$ & $55.81 \%$ & $47.01 \%$ & $38.33 \%$ \\
\hline 3 & $55.77 \%$ & $39.74 \%$ & $31.91 \%$ & $20.97 \%$ & $26.14 \%$ & $28.89 \%$ & $19.80 \%$ & $47.29 \%$ & $39.55 \%$ & $29.17 \%$ \\
\hline 5 & $46.15 \%$ & $30.77 \%$ & $19.15 \%$ & $14.52 \%$ & $21.59 \%$ & $22.22 \%$ & $14.85 \%$ & $38.76 \%$ & $34.33 \%$ & $23.33 \%$ \\
\hline 10 & $36.54 \%$ & $29.49 \%$ & $8.51 \%$ & $4.84 \%$ & - & $6.67 \%$ & - & $31.78 \%$ & $26.12 \%$ & $18.33 \%$ \\
\hline 20 & $9.62 \%$ & $14.10 \%$ & $4.26 \%$ & $1.61 \%$ & $6.82 \%$ & $2.22 \%$ & $3.96 \%$ & $6.98 \%$ & $5.22 \%$ & $5.00 \%$ \\
\hline decline & $87.49 \%$ & $76.60 \%$ & $94.44 \%$ & $96.30 \%$ & $84.61 \%$ & $95.24 \%$ & $89.19 \%$ & $89.28 \%$ & $91.26 \%$ & $89.65 \%$ \\
\hline \multicolumn{11}{|c|}{ Paper making and paper industry } \\
\hline 1 & $61.54 \%$ & $60.87 \%$ & $53.49 \%$ & $48.21 \%$ & $41.89 \%$ & $60.00 \%$ & $46.07 \%$ & $49.37 \%$ & $53.54 \%$ & $50.00 \%$ \\
\hline 2 & $51.92 \%$ & $43.48 \%$ & $48.84 \%$ & $30.36 \%$ & $32.43 \%$ & $28.00 \%$ & $33.71 \%$ & $31.65 \%$ & $35.35 \%$ & $34.91 \%$ \\
\hline 3 & $46.15 \%$ & $36.96 \%$ & $32.56 \%$ & $26.79 \%$ & $24.32 \%$ & - & $25.84 \%$ & $29.11 \%$ & $26.26 \%$ & $30.19 \%$ \\
\hline 5 & $40.38 \%$ & $30.43 \%$ & $16.28 \%$ & - & $18.92 \%$ & - & $24.72 \%$ & $17.72 \%$ & - & $25.47 \%$ \\
\hline 10 & $32.69 \%$ & $23.91 \%$ & $4.65 \%$ & $8.93 \%$ & - & $4.00 \%$ & $15.73 \%$ & $11.39 \%$ & $11.11 \%$ & - \\
\hline 20 & $9.62 \%$ & $8.70 \%$ & $0.00 \%$ & $3.57 \%$ & $5.41 \%$ & $0.00 \%$ & $5.62 \%$ & $1.27 \%$ & $3.03 \%$ & $4.72 \%$ \\
\hline decline & $84.37 \%$ & $85.71 \%$ & l & $92.59 \%$ & $87.09 \%$ & I & $87.80 \%$ & $97.43 \%$ & $94.34 \%$ & $90.56 \%$ \\
\hline \multicolumn{11}{|c|}{ Copy of printing media } \\
\hline 1 & $64.84 \%$ & $60.98 \%$ & $59.46 \%$ & $44.68 \%$ & $42.37 \%$ & $68.00 \%$ & $37.25 \%$ & $67.27 \%$ & $48.25 \%$ & $43.30 \%$ \\
\hline 2 & $49.45 \%$ & $43.90 \%$ & $51.35 \%$ & $34.04 \%$ & $33.90 \%$ & $56.00 \%$ & $16.67 \%$ & $54.55 \%$ & $35.96 \%$ & $34.02 \%$ \\
\hline 3 & $43.96 \%$ & $39.02 \%$ & $35.14 \%$ & $31.91 \%$ & $28.81 \%$ & $44.00 \%$ & $9.80 \%$ & $52.73 \%$ & $28.07 \%$ & $28.87 \%$ \\
\hline 5 & $41.76 \%$ & $24.39 \%$ & $18.92 \%$ & - & $18.64 \%$ & $32.00 \%$ & $6.86 \%$ & $44.55 \%$ & $23.68 \%$ & $22.68 \%$ \\
\hline 10 & $35.16 \%$ & $17.07 \%$ & $8.11 \%$ & $17.02 \%$ & $13.56 \%$ & $4.00 \%$ & - & $38.18 \%$ & - & - \\
\hline 20 & $8.79 \%$ & $7.32 \%$ & $0.00 \%$ & $4.26 \%$ & $5.08 \%$ & $0.00 \%$ & $2.94 \%$ & $10.00 \%$ & $5.26 \%$ & $10.31 \%$ \\
\hline decline & $86.44 \%$ & $88.00 \%$ & I & $90.47 \%$ & $88.01 \%$ & I & $92.11 \%$ & $85.13 \%$ & $89.10 \%$ & $76.19 \%$ \\
\hline
\end{tabular}




\section{Continued}

\begin{tabular}{|c|c|c|c|c|c|c|c|c|c|c|}
\hline \multicolumn{11}{|c|}{ Cultural and educational sports goods manufacturing industry } \\
\hline 1 & $66.67 \%$ & $77.05 \%$ & $73.33 \%$ & $45.95 \%$ & $57.58 \%$ & $66.67 \%$ & $58.43 \%$ & $66.07 \%$ & $60.27 \%$ & $53.62 \%$ \\
\hline 2 & $63.33 \%$ & $63.93 \%$ & $63.33 \%$ & $37.84 \%$ & $33.33 \%$ & $55.56 \%$ & $47.19 \%$ & $50.89 \%$ & $41.10 \%$ & $43.48 \%$ \\
\hline 3 & $56.67 \%$ & $55.74 \%$ & $40.00 \%$ & $29.73 \%$ & $24.24 \%$ & $44.44 \%$ & $37.08 \%$ & $44.64 \%$ & $34.25 \%$ & $40.58 \%$ \\
\hline 5 & $46.67 \%$ & $47.54 \%$ & $30.00 \%$ & $16.22 \%$ & $18.18 \%$ & $29.63 \%$ & $28.09 \%$ & $40.18 \%$ & $19.18 \%$ & $31.88 \%$ \\
\hline 10 & $33.33 \%$ & $40.98 \%$ & $16.67 \%$ & $5.41 \%$ & $12.12 \%$ & $11.11 \%$ & $21.35 \%$ & $30.36 \%$ & $10.96 \%$ & $18.84 \%$ \\
\hline 20 & $10.00 \%$ & $32.79 \%$ & $0.00 \%$ & $0.00 \%$ & $1.52 \%$ & $0.00 \%$ & $4.49 \%$ & $7.14 \%$ & $4.11 \%$ & $8.70 \%$ \\
\hline decline & $85.00 \%$ & $57.44 \%$ & I & I & $97.36 \%$ & I & $92.32 \%$ & $89.19 \%$ & $93.18 \%$ & $83.77 \%$ \\
\hline \multicolumn{11}{|c|}{ Petroleum processing and coking industry } \\
\hline 1 & $60.49 \%$ & $50.00 \%$ & $48.94 \%$ & $51.16 \%$ & $51.64 \%$ & $54.17 \%$ & $36.00 \%$ & $41.94 \%$ & $52.17 \%$ & $47.68 \%$ \\
\hline 2 & $50.62 \%$ & $33.33 \%$ & $34.04 \%$ & $36.05 \%$ & $36.07 \%$ & $33.33 \%$ & $22.67 \%$ & $33.33 \%$ & $28.70 \%$ & $31.79 \%$ \\
\hline 3 & $45.68 \%$ & - & $21.28 \%$ & $32.56 \%$ & $32.79 \%$ & $31.25 \%$ & $12.00 \%$ & $29.03 \%$ & $18.26 \%$ & $25.17 \%$ \\
\hline 5 & $39.51 \%$ & $27.08 \%$ & $17.02 \%$ & $20.93 \%$ & $22.95 \%$ & - & $4.00 \%$ & $21.51 \%$ & $6.09 \%$ & $19.21 \%$ \\
\hline 10 & $27.16 \%$ & $16.67 \%$ & $4.26 \%$ & $15.12 \%$ & - & $12.50 \%$ & $0.00 \%$ & $12.90 \%$ & $3.48 \%$ & $14.57 \%$ \\
\hline 20 & $3.70 \%$ & $6.25 \%$ & $2.13 \%$ & $2.33 \%$ & $4.92 \%$ & $4.17 \%$ & $0.00 \%$ & $0.00 \%$ & $0.00 \%$ & $1.32 \%$ \\
\hline decline & $93.88 \%$ & $87.50 \%$ & $95.65 \%$ & $95.45 \%$ & $90.47 \%$ & $92.30 \%$ & 1 & 1 & 1 & $97.23 \%$ \\
\hline \multicolumn{11}{|c|}{ Chemical raw materials and chemical products manufacturing industry } \\
\hline 1 & $71.88 \%$ & $66.67 \%$ & $75.00 \%$ & $46.67 \%$ & $54.84 \%$ & $78.95 \%$ & $48.05 \%$ & $47.22 \%$ & $68.92 \%$ & $66.00 \%$ \\
\hline 2 & $62.50 \%$ & $62.50 \%$ & $71.43 \%$ & $43.33 \%$ & $46.77 \%$ & $68.42 \%$ & $33.77 \%$ & $34.72 \%$ & $52.70 \%$ & $58.00 \%$ \\
\hline 3 & $53.13 \%$ & $54.17 \%$ & $53.57 \%$ & $36.67 \%$ & $38.71 \%$ & $47.37 \%$ & $32.47 \%$ & $29.17 \%$ & $39.19 \%$ & $54.00 \%$ \\
\hline 5 & $46.88 \%$ & $29.17 \%$ & $39.29 \%$ & $23.33 \%$ & $30.65 \%$ & $31.58 \%$ & $24.68 \%$ & $18.06 \%$ & $18.92 \%$ & $40.00 \%$ \\
\hline 10 & $37.50 \%$ & $12.50 \%$ & $28.57 \%$ & $10.00 \%$ & $25.81 \%$ & $10.53 \%$ & $16.88 \%$ & $13.89 \%$ & - & $34.00 \%$ \\
\hline 20 & $18.75 \%$ & $0.00 \%$ & $3.57 \%$ & $3.33 \%$ & $9.68 \%$ & $0.00 \%$ & $3.90 \%$ & $5.56 \%$ & $4.05 \%$ & $16.00 \%$ \\
\hline decline & $73.91 \%$ & 1 & $95.24 \%$ & $92.86 \%$ & $82.35 \%$ & 1 & $91.88 \%$ & $88.23 \%$ & $94.12 \%$ & $75.76 \%$ \\
\hline \multicolumn{11}{|c|}{ Pharmaceutical manufacturing industry } \\
\hline 1 & $50.68 \%$ & $40.51 \%$ & $35.00 \%$ & $34.92 \%$ & $41.54 \%$ & $35.21 \%$ & $46.15 \%$ & $47.62 \%$ & $31.88 \%$ & $45.65 \%$ \\
\hline 2 & $34.25 \%$ & $30.38 \%$ & $23.33 \%$ & $26.98 \%$ & $27.69 \%$ & $22.54 \%$ & $30.77 \%$ & $24.76 \%$ & $21.74 \%$ & $31.52 \%$ \\
\hline 3 & $26.03 \%$ & $25.32 \%$ & $15.00 \%$ & $19.05 \%$ & $24.62 \%$ & $14.08 \%$ & $21.15 \%$ & $19.05 \%$ & $15.94 \%$ & $28.26 \%$ \\
\hline 5 & $23.29 \%$ & $16.46 \%$ & $10.00 \%$ & $6.35 \%$ & $16.92 \%$ & $9.86 \%$ & $11.54 \%$ & $14.29 \%$ & - & $22.83 \%$ \\
\hline 10 & $17.81 \%$ & $12.66 \%$ & $6.67 \%$ & - & - & - & - & - & - & - \\
\hline 20 & $9.59 \%$ & $3.80 \%$ & $3.33 \%$ & $1.59 \%$ & $0.00 \%$ & $0.00 \%$ & $1.92 \%$ & $1.90 \%$ & $5.80 \%$ & $3.26 \%$ \\
\hline decline & $81.08 \%$ & $90.62 \%$ & $90.49 \%$ & $95.45 \%$ & 1 & 1 & $95.84 \%$ & $96.01 \%$ & $81.81 \%$ & $92.86 \%$ \\
\hline \multicolumn{11}{|c|}{ Chemical fiber manufacturing industry } \\
\hline 1 & $40.63 \%$ & $49.35 \%$ & $51.39 \%$ & $49.23 \%$ & $53.73 \%$ & $38.89 \%$ & $32.56 \%$ & $32.35 \%$ & $28.07 \%$ & $40.00 \%$ \\
\hline 2 & $29.69 \%$ & $33.77 \%$ & $36.11 \%$ & $40.00 \%$ & $37.31 \%$ & $27.78 \%$ & $20.93 \%$ & $16.18 \%$ & $17.54 \%$ & $21.90 \%$ \\
\hline 3 & $22.66 \%$ & $27.27 \%$ & $25.00 \%$ & $33.85 \%$ & $34.33 \%$ & $16.67 \%$ & $13.95 \%$ & $7.35 \%$ & $8.77 \%$ & $17.14 \%$ \\
\hline 5 & $18.75 \%$ & $16.88 \%$ & $19.44 \%$ & - & $26.87 \%$ & $13.89 \%$ & $6.98 \%$ & $0.00 \%$ & - & $8.57 \%$ \\
\hline 10 & $14.84 \%$ & - & $12.50 \%$ & $18.46 \%$ & $14.93 \%$ & - & - & $0.00 \%$ & $0.00 \%$ & - \\
\hline 20 & $2.34 \%$ & $2.60 \%$ & $0.00 \%$ & $3.08 \%$ & $1.49 \%$ & $2.78 \%$ & $2.33 \%$ & $0.00 \%$ & $0.00 \%$ & $1.90 \%$ \\
\hline decline & $94.24 \%$ & $94.73 \%$ & 1 & $93.74 \%$ & $97.23 \%$ & $92.85 \%$ & $92.84 \%$ & I & 1 & $95.25 \%$ \\
\hline
\end{tabular}




\section{Continued}

\begin{tabular}{|c|c|c|c|c|c|c|c|c|c|c|}
\hline \multicolumn{11}{|c|}{ Rubber products industry } \\
\hline 1 & $69.81 \%$ & $45.28 \%$ & $71.43 \%$ & $67.74 \%$ & $70.27 \%$ & $52.94 \%$ & $49.54 \%$ & $51.85 \%$ & $41.77 \%$ & $61.64 \%$ \\
\hline 2 & $60.38 \%$ & $35.85 \%$ & $51.43 \%$ & $51.61 \%$ & $51.35 \%$ & $41.18 \%$ & $37.61 \%$ & $40.74 \%$ & $31.65 \%$ & $49.32 \%$ \\
\hline 3 & $52.83 \%$ & $33.96 \%$ & $42.86 \%$ & $33.85 \%$ & $48.65 \%$ & $32.35 \%$ & $29.36 \%$ & $29.63 \%$ & $27.85 \%$ & $42.47 \%$ \\
\hline 5 & $45.28 \%$ & $26.42 \%$ & $22.86 \%$ & $32.26 \%$ & $37.84 \%$ & $23.53 \%$ & $25.69 \%$ & $25.93 \%$ & $17.72 \%$ & $39.73 \%$ \\
\hline 10 & $39.62 \%$ & $18.87 \%$ & $8.57 \%$ & $19.35 \%$ & $32.43 \%$ & $11.76 \%$ & - & - & $11.39 \%$ & $32.88 \%$ \\
\hline 20 & $13.21 \%$ & $7.55 \%$ & $2.86 \%$ & $9.68 \%$ & $5.41 \%$ & $2.94 \%$ & $7.34 \%$ & $4.94 \%$ & $1.27 \%$ & $10.96 \%$ \\
\hline decline & $81.08 \%$ & $83.33 \%$ & $96.00 \%$ & $85.71 \%$ & $92.30 \%$ & $94.45 \%$ & $85.18 \%$ & $90.47 \%$ & $96.96 \%$ & $82.22 \%$ \\
\hline \multicolumn{11}{|c|}{ Plastics industry } \\
\hline 1 & $69.57 \%$ & $52.08 \%$ & $54.05 \%$ & $57.14 \%$ & $56.67 \%$ & $68.97 \%$ & $43.43 \%$ & $52.53 \%$ & $52.17 \%$ & $51.25 \%$ \\
\hline 2 & $63.04 \%$ & $41.67 \%$ & $48.65 \%$ & $39.29 \%$ & $48.33 \%$ & $37.93 \%$ & $30.30 \%$ & $35.35 \%$ & $36.96 \%$ & $36.25 \%$ \\
\hline 3 & $56.52 \%$ & $39.58 \%$ & $32.43 \%$ & $32.14 \%$ & $41.67 \%$ & $34.48 \%$ & $23.23 \%$ & $30.30 \%$ & $30.43 \%$ & $35.00 \%$ \\
\hline 5 & $50.00 \%$ & $31.25 \%$ & $27.03 \%$ & $19.64 \%$ & $36.67 \%$ & $27.59 \%$ & $16.16 \%$ & $22.22 \%$ & $21.74 \%$ & $27.50 \%$ \\
\hline 10 & $41.30 \%$ & $25.00 \%$ & $13.51 \%$ & $8.93 \%$ & $28.33 \%$ & $6.90 \%$ & $10.10 \%$ & $18.18 \%$ & $19.57 \%$ & - \\
\hline 20 & $10.87 \%$ & $6.25 \%$ & $2.70 \%$ & $5.36 \%$ & $8.33 \%$ & $3.45 \%$ & $6.06 \%$ & $7.07 \%$ & $4.35 \%$ & $8.75 \%$ \\
\hline decline & $84.38 \%$ & $88.00 \%$ & $95.00 \%$ & $90.62 \%$ & $85.30 \%$ & $95.00 \%$ & $86.05 \%$ & $86.54 \%$ & $91.66 \%$ & $82.93 \%$ \\
\hline \multicolumn{11}{|c|}{ Nonmetallic mineral products industry } \\
\hline 1 & $70.37 \%$ & $54.17 \%$ & $63.64 \%$ & $59.46 \%$ & $56.52 \%$ & $61.76 \%$ & $44.05 \%$ & $47.37 \%$ & $47.25 \%$ & $44.30 \%$ \\
\hline 2 & $55.56 \%$ & $35.42 \%$ & $54.55 \%$ & $48.65 \%$ & $43.48 \%$ & $38.24 \%$ & $26.19 \%$ & $31.58 \%$ & $34.07 \%$ & $36.71 \%$ \\
\hline 3 & $48.15 \%$ & $31.25 \%$ & $42.42 \%$ & $43.24 \%$ & $36.23 \%$ & $29.41 \%$ & $20.24 \%$ & $27.37 \%$ & $25.27 \%$ & $32.91 \%$ \\
\hline 5 & $40.74 \%$ & $20.83 \%$ & $30.30 \%$ & $35.14 \%$ & $28.99 \%$ & $20.59 \%$ & $17.86 \%$ & $17.89 \%$ & $17.58 \%$ & $29.11 \%$ \\
\hline 10 & $29.63 \%$ & $8.33 \%$ & $15.15 \%$ & $21.62 \%$ & $23.19 \%$ & $8.82 \%$ & $11.90 \%$ & - & - & $21.52 \%$ \\
\hline 20 & $3.70 \%$ & $0.00 \%$ & $3.03 \%$ & $5.41 \%$ & $8.70 \%$ & $2.94 \%$ & $2.38 \%$ & $2.11 \%$ & $3.30 \%$ & $5.06 \%$ \\
\hline decline & $94.74 \%$ & I & $95.24 \%$ & $90.90 \%$ & $84.61 \%$ & $95.24 \%$ & $94.60 \%$ & $95.55 \%$ & $93.02 \%$ & $88.58 \%$ \\
\hline \multicolumn{11}{|c|}{ Ferrous metal smelting and calendaring industry } \\
\hline 1 & $58.73 \%$ & $58.18 \%$ & $53.19 \%$ & $42.00 \%$ & $50.62 \%$ & $67.65 \%$ & $38.54 \%$ & $47.73 \%$ & $44.32 \%$ & $64.52 \%$ \\
\hline 2 & $50.79 \%$ & $43.64 \%$ & $44.68 \%$ & $34.00 \%$ & $43.21 \%$ & $47.06 \%$ & $15.62 \%$ & $37.50 \%$ & $20.45 \%$ & $50.54 \%$ \\
\hline 3 & $44.44 \%$ & $30.91 \%$ & $38.30 \%$ & $28.00 \%$ & $38.27 \%$ & $38.24 \%$ & $10.42 \%$ & $26.14 \%$ & $13.64 \%$ & $38.71 \%$ \\
\hline 5 & $39.68 \%$ & $27.27 \%$ & $23.40 \%$ & $16.00 \%$ & $28.40 \%$ & $29.41 \%$ & - & $21.59 \%$ & $6.82 \%$ & $35.48 \%$ \\
\hline 10 & $36.51 \%$ & $16.36 \%$ & $14.89 \%$ & $12.00 \%$ & $25.93 \%$ & $20.59 \%$ & $2.08 \%$ & $13.64 \%$ & - & $33.33 \%$ \\
\hline 20 & $11.11 \%$ & $7.27 \%$ & $6.38 \%$ & $4.00 \%$ & $7.41 \%$ & $8.82 \%$ & $0.00 \%$ & $3.41 \%$ & $1.14 \%$ & $8.60 \%$ \\
\hline decline & $81.08 \%$ & $87.50 \%$ & $88.01 \%$ & $90.48 \%$ & $85.36 \%$ & $86.96 \%$ & 1 & $92.86 \%$ & $97.43 \%$ & $86.67 \%$ \\
\hline \multicolumn{11}{|c|}{ Nonferrous metal smelting and calendaring processing industry } \\
\hline 1 & $63.51 \%$ & $68.63 \%$ & $57.45 \%$ & $50.00 \%$ & $48.35 \%$ & $62.50 \%$ & $34.74 \%$ & $50.54 \%$ & $26.97 \%$ & $56.31 \%$ \\
\hline 2 & $54.05 \%$ & $47.06 \%$ & $40.43 \%$ & $31.43 \%$ & $29.67 \%$ & $37.50 \%$ & $22.11 \%$ & $31.18 \%$ & $19.10 \%$ & $39.81 \%$ \\
\hline 3 & $50.00 \%$ & $39.22 \%$ & $27.66 \%$ & $25.71 \%$ & $26.37 \%$ & $31.25 \%$ & $15.79 \%$ & $26.88 \%$ & $12.36 \%$ & $31.07 \%$ \\
\hline 5 & $43.24 \%$ & $31.37 \%$ & $19.15 \%$ & - & - & - & $12.63 \%$ & $13.98 \%$ & - & $25.24 \%$ \\
\hline 10 & $37.84 \%$ & $25.49 \%$ & $8.51 \%$ & $15.71 \%$ & $14.29 \%$ & $12.50 \%$ & $7.37 \%$ & - & $6.74 \%$ & $22.33 \%$ \\
\hline 20 & $9.46 \%$ & $11.76 \%$ & $4.26 \%$ & $5.71 \%$ & $5.49 \%$ & $6.25 \%$ & $2.11 \%$ & $3.23 \%$ & $2.25 \%$ & $4.85 \%$ \\
\hline decline & $85.10 \%$ & $82.86 \%$ & $92.58 \%$ & $88.58 \%$ & $88.65 \%$ & $90.00 \%$ & $93.93 \%$ & $93.61 \%$ & $91.66 \%$ & $91.39 \%$ \\
\hline
\end{tabular}




\section{Continued}

\begin{tabular}{|c|c|c|c|c|c|c|c|c|c|c|}
\hline \multicolumn{11}{|c|}{ Metal products industry } \\
\hline 1 & $51.85 \%$ & $66.67 \%$ & $86.67 \%$ & $65.79 \%$ & $48.28 \%$ & $59.09 \%$ & $46.60 \%$ & $62.37 \%$ & $50.00 \%$ & $55.71 \%$ \\
\hline 2 & $44.44 \%$ & $55.56 \%$ & $76.67 \%$ & $42.11 \%$ & $36.21 \%$ & $50.00 \%$ & $33.98 \%$ & $51.61 \%$ & $35.00 \%$ & $48.57 \%$ \\
\hline 3 & $33.33 \%$ & $53.33 \%$ & $50.00 \%$ & $34.21 \%$ & $34.48 \%$ & $31.82 \%$ & $31.07 \%$ & $48.39 \%$ & $23.75 \%$ & $45.71 \%$ \\
\hline 5 & $22.22 \%$ & $37.78 \%$ & $40.00 \%$ & $26.32 \%$ & $27.59 \%$ & $22.73 \%$ & $21.36 \%$ & $39.78 \%$ & $15.00 \%$ & $38.57 \%$ \\
\hline 10 & $14.81 \%$ & $31.11 \%$ & $16.67 \%$ & $15.79 \%$ & $24.14 \%$ & $9.09 \%$ & $15.53 \%$ & $31.18 \%$ & - & $31.43 \%$ \\
\hline 20 & $3.70 \%$ & $13.33 \%$ & $0.00 \%$ & $7.89 \%$ & $5.17 \%$ & $4.55 \%$ & $6.80 \%$ & $8.60 \%$ & $2.50 \%$ & $10.00 \%$ \\
\hline decline & $92.86 \%$ & $80.01 \%$ & I & $88.01 \%$ & $89.29 \%$ & $92.30 \%$ & $85.41 \%$ & $86.21 \%$ & $95.00 \%$ & $82.05 \%$ \\
\hline \multicolumn{11}{|c|}{ General machinery manufacturing industry } \\
\hline 1 & $70.00 \%$ & $83.33 \%$ & $92.31 \%$ & $50.00 \%$ & $62.22 \%$ & $70.00 \%$ & $48.78 \%$ & $52.54 \%$ & $66.18 \%$ & $61.19 \%$ \\
\hline 2 & $66.67 \%$ & $70.83 \%$ & $84.62 \%$ & $45.45 \%$ & $51.11 \%$ & $60.00 \%$ & $40.24 \%$ & $37.29 \%$ & $57.35 \%$ & $46.27 \%$ \\
\hline 3 & $56.67 \%$ & - & $69.23 \%$ & - & $42.22 \%$ & $45.00 \%$ & $34.15 \%$ & $35.59 \%$ & $41.18 \%$ & $44.78 \%$ \\
\hline 5 & $43.33 \%$ & $54.17 \%$ & $61.54 \%$ & $31.82 \%$ & $31.11 \%$ & $30.00 \%$ & $28.05 \%$ & $28.81 \%$ & $20.59 \%$ & $38.81 \%$ \\
\hline 10 & $36.67 \%$ & $33.33 \%$ & $42.31 \%$ & $13.64 \%$ & $24.44 \%$ & $15.00 \%$ & $20.73 \%$ & $23.73 \%$ & $16.18 \%$ & $28.36 \%$ \\
\hline 20 & $16.67 \%$ & $8.33 \%$ & $3.85 \%$ & $0.00 \%$ & $4.44 \%$ & $0.00 \%$ & $2.44 \%$ & $1.69 \%$ & $4.41 \%$ & $10.45 \%$ \\
\hline decline & $76.19 \%$ & $90.00 \%$ & $95.83 \%$ & I & $92.86 \%$ & I & $95.00 \%$ & $96.78 \%$ & $93.34 \%$ & $82.92 \%$ \\
\hline \multicolumn{11}{|c|}{ Special equipment manufacturing industry } \\
\hline 1 & $56.41 \%$ & $76.92 \%$ & $73.33 \%$ & $62.07 \%$ & $56.36 \%$ & $76.19 \%$ & $49.50 \%$ & $64.94 \%$ & $54.22 \%$ & $52.63 \%$ \\
\hline 2 & $46.15 \%$ & $61.54 \%$ & $66.67 \%$ & $48.28 \%$ & $47.27 \%$ & $61.90 \%$ & $35.64 \%$ & $45.45 \%$ & $42.17 \%$ & $42.11 \%$ \\
\hline 3 & $38.46 \%$ & - & $53.33 \%$ & $44.83 \%$ & $41.82 \%$ & $47.62 \%$ & $29.70 \%$ & $44.16 \%$ & $31.33 \%$ & $34.21 \%$ \\
\hline 5 & $30.77 \%$ & $48.72 \%$ & $46.67 \%$ & $27.59 \%$ & $29.09 \%$ & $23.81 \%$ & $20.79 \%$ & $35.06 \%$ & $16.87 \%$ & $28.95 \%$ \\
\hline 10 & $23.08 \%$ & $30.77 \%$ & $30.00 \%$ & $17.24 \%$ & $23.64 \%$ & $9.52 \%$ & $14.85 \%$ & $28.57 \%$ & $10.84 \%$ & $22.37 \%$ \\
\hline 20 & $7.69 \%$ & $10.26 \%$ & $0.00 \%$ & $6.90 \%$ & $9.09 \%$ & $0.00 \%$ & $5.94 \%$ & $2.60 \%$ & $2.41 \%$ & $9.21 \%$ \\
\hline decline & $86.37 \%$ & $86.66 \%$ & 1 & $88.88 \%$ & $83.87 \%$ & I & $88.00 \%$ & $96.00 \%$ & $95.56 \%$ & $82.50 \%$ \\
\hline \multicolumn{11}{|c|}{ Transportation equipment manufacturing industry } \\
\hline 1 & $72.73 \%$ & $71.43 \%$ & $74.29 \%$ & $56.25 \%$ & $73.68 \%$ & $72.73 \%$ & $49.07 \%$ & $63.77 \%$ & $59.41 \%$ & $52.38 \%$ \\
\hline 2 & $63.64 \%$ & $60.71 \%$ & $57.14 \%$ & $50.00 \%$ & $68.42 \%$ & $54.55 \%$ & $36.11 \%$ & $42.03 \%$ & $45.54 \%$ & $36.51 \%$ \\
\hline 3 & $57.58 \%$ & $57.14 \%$ & $45.71 \%$ & - & $63.16 \%$ & $36.36 \%$ & $29.63 \%$ & $37.68 \%$ & $32.67 \%$ & $26.98 \%$ \\
\hline 5 & $48.48 \%$ & $39.29 \%$ & $37.14 \%$ & $31.25 \%$ & $52.63 \%$ & $22.73 \%$ & $24.07 \%$ & $30.43 \%$ & $24.75 \%$ & $19.05 \%$ \\
\hline 10 & $39.39 \%$ & $28.57 \%$ & $17.14 \%$ & $12.50 \%$ & $47.37 \%$ & $9.09 \%$ & $19.44 \%$ & $20.29 \%$ & - & $14.29 \%$ \\
\hline 20 & $0.00 \%$ & $3.57 \%$ & $0.00 \%$ & $6.25 \%$ & $18.42 \%$ & $0.00 \%$ & $7.41 \%$ & $5.80 \%$ & $7.92 \%$ & $6.35 \%$ \\
\hline decline & l & $95.00 \%$ & / & $88.89 \%$ & $75.00 \%$ & l & $84.90 \%$ & $90.90 \%$ & $86.67 \%$ & $87.88 \%$ \\
\hline \multicolumn{11}{|c|}{ Electrical machinery and equipment manufacturing } \\
\hline 1 & $67.65 \%$ & $71.43 \%$ & $80.00 \%$ & $60.00 \%$ & $61.70 \%$ & $70.83 \%$ & $58.82 \%$ & $62.35 \%$ & $76.67 \%$ & $68.35 \%$ \\
\hline 2 & $55.88 \%$ & $51.43 \%$ & - & $56.00 \%$ & $46.81 \%$ & $62.50 \%$ & $43.14 \%$ & $38.82 \%$ & $61.67 \%$ & $46.84 \%$ \\
\hline 3 & $44.12 \%$ & $48.57 \%$ & $60.00 \%$ & - & $40.43 \%$ & $41.67 \%$ & $36.27 \%$ & $34.12 \%$ & $50.00 \%$ & $37.97 \%$ \\
\hline 5 & $38.24 \%$ & $37.14 \%$ & $48.00 \%$ & $32.00 \%$ & $34.04 \%$ & $29.17 \%$ & $27.45 \%$ & $27.06 \%$ & $26.67 \%$ & $31.65 \%$ \\
\hline 10 & $26.47 \%$ & $25.71 \%$ & $12.00 \%$ & $20.00 \%$ & $27.66 \%$ & $12.50 \%$ & $18.63 \%$ & $24.71 \%$ & $20.00 \%$ & $27.85 \%$ \\
\hline 20 & $8.82 \%$ & $11.43 \%$ & $0.00 \%$ & $4.00 \%$ & $12.77 \%$ & $4.17 \%$ & $8.82 \%$ & $5.88 \%$ & $6.67 \%$ & $11.39 \%$ \\
\hline decline & $86.96 \%$ & $84.00 \%$ & I & $93.33 \%$ & $79.30 \%$ & $94.11 \%$ & $85.01 \%$ & $90.57 \%$ & $91.30 \%$ & $83.34 \%$ \\
\hline
\end{tabular}




\section{Continued}

\begin{tabular}{ccccccccccc}
\hline \multicolumn{7}{c}{ Electronic and communication equipment manufacturing industry } \\
\hline 1 & $62.79 \%$ & $62.96 \%$ & $62.50 \%$ & $55.88 \%$ & $55.10 \%$ & $55.56 \%$ & $40.57 \%$ & $60.49 \%$ & $65.08 \%$ & $42.11 \%$ \\
2 & $48.84 \%$ & $48.15 \%$ & $52.50 \%$ & $44.12 \%$ & $38.78 \%$ & $51.85 \%$ & $28.30 \%$ & $48.15 \%$ & $49.21 \%$ & $27.19 \%$ \\
3 & $44.19 \%$ & $40.74 \%$ & $40.00 \%$ & $38.24 \%$ & $32.65 \%$ & $37.04 \%$ & $25.47 \%$ & $41.98 \%$ & $46.03 \%$ & $23.68 \%$ \\
5 & $37.21 \%$ & $22.22 \%$ & $27.50 \%$ & $20.59 \%$ & $22.45 \%$ & $22.22 \%$ & $19.81 \%$ & $32.10 \%$ & $23.81 \%$ & $17.54 \%$ \\
10 & $25.58 \%$ & $14.81 \%$ & $12.50 \%$ & $5.88 \%$ & $18.37 \%$ & $11.11 \%$ & $14.15 \%$ & $25.93 \%$ & $15.87 \%$ & $11.40 \%$ \\
20 & $4.65 \%$ & $3.70 \%$ & $0.00 \%$ & $0.00 \%$ & $0.00 \%$ & $0.00 \%$ & $4.72 \%$ & $13.58 \%$ & $4.76 \%$ & $0.88 \%$ \\
decline & $92.59 \%$ & $94.12 \%$ & $/$ & $/$ & $/$ & $/$ & $88.37 \%$ & $77.55 \%$ & $92.69 \%$ & $97.91 \%$ \\
\hline & & & & Instrument and cultural office machinery & & & & \\
\hline 1 & $57.41 \%$ & $68.75 \%$ & $65.63 \%$ & $56.67 \%$ & $50.00 \%$ & $82.61 \%$ & $45.88 \%$ & $64.95 \%$ & $46.48 \%$ & $54.26 \%$ \\
2 & $48.15 \%$ & $50.00 \%$ & $59.38 \%$ & $43.33 \%$ & $36.76 \%$ & $60.87 \%$ & $32.94 \%$ & $50.52 \%$ & $36.62 \%$ & $42.55 \%$ \\
3 & $42.59 \%$ & $46.88 \%$ & $46.88 \%$ & $40.00 \%$ & $29.41 \%$ & $47.83 \%$ & $24.71 \%$ & $43.30 \%$ & $26.76 \%$ & $35.11 \%$ \\
5 & $37.04 \%$ & $34.38 \%$ & $40.63 \%$ & $23.33 \%$ & - & $34.78 \%$ & $17.65 \%$ & $36.08 \%$ & $11.27 \%$ & $29.79 \%$ \\
10 & $29.63 \%$ & $21.88 \%$ & $18.75 \%$ & $16.67 \%$ & $16.18 \%$ & $17.39 \%$ & $8.24 \%$ & $29.90 \%$ & $5.63 \%$ & - \\
20 & $7.41 \%$ & $3.13 \%$ & $0.00 \%$ & $0.00 \%$ & $1.47 \%$ & $4.35 \%$ & $1.18 \%$ & $8.25 \%$ & $0.00 \%$ & $7.45 \%$ \\
decline & $87.09 \%$ & $95.45 \%$ & $/$ & $/$ & $97.06 \%$ & $94.73 \%$ & $97.43 \%$ & $87.30 \%$ & $/$ & $86.27 \%$ \\
\hline
\end{tabular}

Note: 1) the time in the table is excerpt; 2) "-" means that a certain type of manufacturing product does not have the duration, so it is unable to calculate the survival rate. For example, the Instrument and cultural office machinery of Korea does not have trade relations whose length of duration is 10 years, so this product has no survival rate; 3 ) the longest trading relationship is 20 years, but there are still many trade relationships which have not reached 20 years, so when $t=20$, the survival rate was 0 . Source: Authors calculation results.

As a whole, the survival rate of the sub-sectors' products of the ten countries is decreasing year by year, which is the same as the previous research conclusions.

Although the survival rate of all sample countries is the same in all manufacturing sectors, but from the reduction if the survival rate we can see that different manufacturing sectors decreases differently. And the larger the decline is, the more unstable the export is. Compared with other Top 10 countries, most China's manufacturing sub-sectors have smaller declines, which indicates that most of the manufacturing sub-sectors' export trade is relatively stable. But there are still some sectors has large instability, such as wood processing and grass and bamboo products industry, oil processing and coking industry, chemical fiber manufacturing industry, non-metallic mineral products, metal products industry, electronic and communication equipment manufacturing industry.

\section{Conclusions and Enlightenment}

The duration of export trade in manufacturing sub-sectors is crucial for the sustainable development of export trade. Therefore, this paper using the survival analysis method studies the duration of the export trade of the top ten countries represented as China, America, and Germany from 1995 to 2015 in manufacturing sub-sectors. We found that China can maintain a long time trade relationship in the export trade of the manufacturing industry, and from the cross-countries comparison of median survival time and survival rate in manufacturing sub-sectors, we conclude that China's export trade has different per- 
formances in different sub-sectors. Specifically, 1) the median survival time of China is generally longer than other countries. Except for the tobacco processing industry, textile industry, chemical fiber manufacturing industry, metal products industry and special equipment manufacturing industry, the median survival time of China is longer than the average survival time of the other ten countries, which indicates that most manufacturing industry sub-sectors in China can maintain long trade relationships in export trade. 2) The survival rate of the sub-sectors' products of the ten countries is decreasing year by year. Compared with other Top 10 countries, most China's manufacturing sub-sectors have smaller declines, which indicates that most of the manufacturing sub-sectors' export trade is relatively stable. But there are still some sectors that have large instability.

This paper provides a more specific and more targeted perspective for achieving the stability of China's export trade in manufacturing industry by cross-countries comparison of duration of trade relationships in manufacturing sub-sectors. On account of that China's export trade has different performances in different manufacturing sub-sectors, the formulation of related trade policy should be formulated differing from different sectors. While keeping the advantages of existing duration of trade relationships, for the products with higher export risk, we should focus on maintaining their trade relationships and making their survival longer. For the sectors with low stability in the early days of trade, the country should make support policy to help the export enterprises in these sectors and improve their trade competitiveness.

\section{References}

[1] Miao, Y. (2013) China Ranks First in the World in Output of 220 Kinds of Industrial Products, Xian Hua Net. http://news.xinhuanet.com/fortune/2013-03/25/c_115145563.htm

[2] Zhang, Y.B., Li, M. and Li, J.W. (2014) Survival Analysis and Cross-National Comparative Study of China's Export in Manufacturing Industry. Journal of International Trade, 11, 3-13.

[3] Besedes, T. and Prusa, T.J. (2006) Ins, Outs, and the Duration of Trade. Canadian Journal of Economics, 39, 266-295. https://doi.org/10.1111/j.0008-4085.2006.00347.x

[4] Besedes, T. and Prusa, T.J. (2006) Product Differentiation and Duration of US Import Trade. Journal of International Economics, 70, 339-358. https://doi.org/10.1016/j.jinteco.2005.12.005

[5] Nitsch, V. (2009) Die Another Day: Duration in German Import Trade. Review of World Economics, 145, 133-154. https://doi.org/10.1007/s10290-009-0008-3

[6] Hess, W. and Person, M. (2010) Exploring the Duration of EU Imports. Department of Economies Working Paper, Lund University.

[7] Besede, T. and Juan, B. (2010) What Drives Exports Survival? An Analysis of Export Duration in Latin America. NBER Working Paper.

[8] Shao, Y. (2011) An Analysis of the Duration of China's Export Trade Relation and Its Influencing Factors. Management World (Monthly), 6, 24-33. 
[9] Chen, Y.B., Li, Y. and Zhou, S.M. (2012) The Duration of Firm-Destination Export Relationships: Evidence from China. Economic Research Journal, 7, 48-61.

[10] Jiang, L.D. and Chen, Y.B. (2015) The Heterogeneity and Export Duration of Export Commodity. The Journal of World Economy, 7, 3-26.

[11] Chen, Y.B., Jiang, L.D. and Cao, L. (2012) Duration of China's Agricultural Product Export and Its Impact Factor Analysis. Issues in Agricultural Economy (Monthly), 11, 7-15.

[12] Lin, C.Q. (2014) Study on Duration of China's Export to US and Its Influencing Factors. Journal of International Trade, 1, 61-70.

[13] Chen, X.H. and Shen, C.Y. (2015) Study on Effects of Export Duration on Export Quality. Journal of International Trade, 1, 47-57. 